Vol. 17 (2008): 394-412.

\title{
Variability of herbage production in mixed leys as related to ley age and environmental factors: a farm survey
}

\author{
Paul Riesinger* and Irina Herzon \\ Department of Applied Biology, PO Box 27, FI-00014 University of Helsinki, Finland, \\ *e-mail:paul.riesinger@novia.fi
}

\begin{abstract}
Influences of ley age, soil properties, and geographical location on the herbage production of red clover-grass leys were determined under practical conditions on 27 organic farms located in the southern and in the northwestern coastal regions of Finland. Averaged over one-, two-, and three-year-old leys the accumulated first and second cuts produced $7.12 \mathrm{t}$ dry matter herbage $\mathrm{ha}^{-1} \mathrm{year}^{-1}$, with a clover proportion of $34.8 \%$. Herbage production declined with increasing ley age. The average proportion of clover increased from $26.4 \%$ in the first to $43.7 \%$ in the second cut but decreased with ley age. Within- and between-field variations of clover proportions markedly decreased from the first to the second cut and strongly increased with ley age, while changes in the variations of herbage production were less pronounced. Within-field variations of clover proportions in the first and in the second cuts were higher at lower proportions of clover. Herbage production was positively related with clover proportion. Soil properties had a major impact on clover proportion and herbage production, largely explaining also regional differences in ley growth. Amelioration of fields and, not at least, of less fertile sites within the same field seems to be a crucial requirement for higher and more even clover proportions and herbage yields.
\end{abstract}

Key-words: Finland, organic farming, proportion of clover, red clover-grass ley, soil properties, spatial heterogeneity, Trifolium pratense

\section{Introduction}

Grasses and clovers are commonly grown as forage (Hopkins and Wilkins 2006), green manure (Wivstad
1997), catch (Känkänen et al. 2001), and understorey crops (Bergkvist 2003). In Fennoscandia with its relatively short growing season, higher herbage production is achieved with perennial forage crops than with annual species. Compared with pure stands of 
Vol. 17 (2008): 394-412.

either grasses or clovers, mixed swards especially of perennial ley crops generally produce more herbage (Halling et al. 2001). However, herbage production and clover proportions have been found to fluctuate markedly on spatial, intra-annual, and inter-annual scales (Jørgensen et al. 1994, Mela 2003, Herrmann et al. 2005). Variability of herbage growth is caused by variations in weather conditions, soil properties and management; the competitive balance between grasses and clovers depends on the physiological characteristics of the plants (Frame et al. 1998, Schulte et al. 2003).

Soil texture and soil organic matter determine soil structure, water retention, and nutrient cycling, i.e., factors that decisively affect crop growth (Stenberg 1998, Thomsen et al. 2003). Grassland growth responds positively to supply with plant nutrients, e.g. with N (Griffin et al. 2002), P (Schils and Snijders 2004), and K (Pant et al. 2004). On acid soils, liming contributes to increased grassland productivity (Ritchey et al. 2004). Spatial and temporal heterogeneity of soil properties is high not only between fields but also within single fields, and contributes strongly to the variability of crop growth (Geypens et al. 1999, Shi et al. 2002).

The over-yielding effect of clover-grass mixtures is largely due to $\mathrm{N}_{2}$ fixation by the Rhizobium-clover symbiosis, and subsequent transfer of $\mathrm{N}$ from clovers to grasses. Ample supply of $\mathrm{N}$ from soil pools or fertilization reduces the competitiveness of the clover relative to the grass component (Høgh-Jensen and Schjoerring 1997). Grasses have a lower temperature optimum than clovers and dominate in mixed stands usually in the first cut (Raininko 1968). The subsequent regrowth may be hampered by drought and lower concentrations of soil N. Under such conditions, the deeper root system and the capacity for symbiotic $\mathrm{N}_{2}$ fixation provide red clover (Trifolium pratense L.) with a competitive advantage over grasses (Raininko 1968). Temperature during regrowth is a key determinant of clover growth (Halling et al. 2004).

While Høgh-Jensen et al. (2001) and Schils and Snijders (2004) reported that application of $\mathrm{P}$ and $\mathrm{K}$ to mixed swards favoured the competitive ability of perennial ryegrass relative to white clover, Acuña and Wilman (1993) and Fortune et al. (2005) did not find any evidence of added P or/ and $\mathrm{K}$ increasing the competitive power of either grasses or clovers. Owing to greater root length and surface area, many grasses compete strongly with clovers for soil nutrients (Mengel and Steffens 1985, Høgh-Jensen and Pedersen 2003). Lower requirements of $\mathrm{P}, \mathrm{K}$, and $\mathrm{Mg}$ may additionally increase the competitiveness of grasses in relation to clovers (Ozanne and Petch 1978, Wheeler 1996, Brennan and Bolland 2006). In soils deficient in N, however, symbiotic $\mathrm{N}_{2}$ fixation provides legumes with a competitive advantage in relation to grasses. Under such conditions, added $\mathrm{P}$ and $\mathrm{K}$ might increase the competitiveness of clovers in relation to grasses (Simpson et al. 1988, Acuña and Wilman 1993, Kirkham et al. 1996).

In northern Europe the overwintering of ley swards is jeopardised by a number of abiotic and biotic factors, including freezing, frost heaving, flooding, ice encasement, and low-temperature fungal attack (Lindén et al. 1999). Ley legumes are to a larger extent than grasses affected by detrimental overwintering conditions (Rufelt 1986, Lager 2002). The overwintering ability of red clover is better in mixed swards with grasses than in pure stands (Belzile 1987, Halling et al. 2001). A competitive companion crop will, however, limit the proportion of clover; timothy (Phleum pratense L.) was shown to be most compatible with red clover (Raininko 1968, Frame et al. 1985). The harvest regime is critical with respect to the maintenance of a productive sward with a reasonably high proportion of clover. Intervals between cuts as well as between the last cut and the first killing frost have to be long enough to allow for sufficient accumulation of the energy and nutrient reserves necessary for persistence and regrowth (Bélanger et al. 2006).

Herbage obtained with a higher cutting frequency is characterised by higher digestibility and a higher protein concentration. In Finnish conditions, however, increasing the harvest intensity from two to three or four cuts not only lowers the annual dry matter (DM) yield but impairs the viability of timothy and red clover. Meadow fescue (Festuca pratensis Huds.), on the other hand, has a better regrowth ability than timothy or red clover (Pulli 
Riesinger, P. \& Herzon, I. Variability of herbage production

1980, Nissinen and Hakkola 1995, Mela 2003). Consequently, in Finnish conditions a harvest system involving three or four cuts is recommended for meadow fescue leys (Pulli 1980) whereas timothy and red clover-grass leys are usually cut only twice (cf. Halling et al. 2001, Nykänen 2008).

On-farm research plays an important role in the understanding and development of agricultural systems (Schiere et al. 1999). We surveyed perennial red clover-grass leys on a number of organic farms in two coastal regions of Finland. Our objectives were (i) to document herbage production and clover proportions of perennial mixed leys managed organically under farming conditions in the coastal regions of Finland, (ii) to quantify between- and within-field variation in herbage production and clover proportion, and (iii) to examine the role of ley age, soil properties, and geographical location in determining ley production and proportion of clover. By relating observations from this explorative study to knowledge gained by experimental studies we intended to test how well established growth patterns and soil/plant relationships hold under practical conditions, to guide farm management, and to contribute to further research (cf. Schjønning et al. 2004).

\section{Material and methods}

\section{Environmental conditions and farm management}

The fields included in this study were located in the coastal area of Finland from $60^{\circ}$ to $65^{\circ}$ North, in two regions in the South and in the North-West, thereafter referred to as "south" and "northwest" (Fig. 1). These two regions differ in climate and soils (Mukula and Rantanen 1987) and therefore the results were grouped by region. Herbage samples were collected during the growing seasons of 2001 and 2002. The weather conditions during these seasons differed but the growing periods were consistently longer, warmer and drier in the south than in the northwest (Appendix, Table 1).

Ley crops were sampled on 27 organic farms (European Council 1991). The farms were selected from registers provided by the regional extension services. Sixteen farms had livestock (10 farms in the south, 6 in the northwest), and 11 were stockless ( 9 farms in the south, 2 in the northwest). The crop rotations of all farms included ley and grain crops. On all farms, primary tillage was carried out by ploughing either in autumn or in spring, and the seedbed was prepared by harrowing in spring. Except for two farms animal manure obtained either from the farm's own livestock or from other farms was applied during the course of a crop rotation. Animal manure primarily was ploughed down prior to ley establishment.

The seed mixtures included red clover (27 farms), timothy (25 farms), and meadow fescue (18 farms). In 16 cases alsike clover (Trifolium hybridum L.), white clover (Trifolium repens L.), or both, were added in small proportions; however, red clover was the dominating legume in all leys. The average amount of ley seed was $21.3 \mathrm{~kg} \mathrm{ha}^{-1}$ $\left(\mathrm{SD}=5.8 \mathrm{~kg} \mathrm{ha}^{-1}\right)$, and the average proportion of clover (by weight) of the seed mixtures was $29.0 \%$

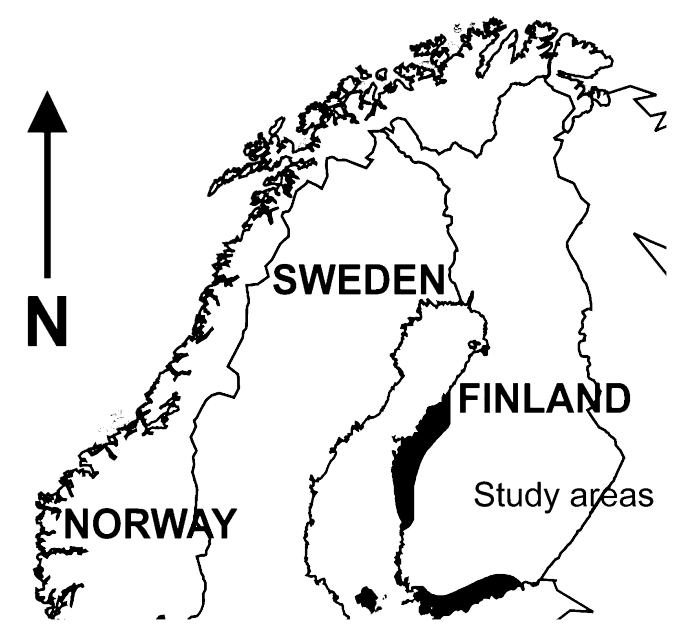

Fig. 1. Location of study areas. 
Vol. 17 (2008): 394-412.

$(\mathrm{SD}=10.2 \%)$. With the exception of one farm (two ley crops) the leys were established with cereal nurse crops. The nurse crops were threshed; only on one farm (four ley crops) the cereal nurse crop was cut for silage at milk ripeness. No harvest was taken from the leys during the establishment year.

On all farms the leys were cut twice per season. On stockless farms, the first cut was either harvested or left in the field as green manure whereas the second cut was always left in the field; the leys were terminated one or two years after the establishment year. On livestock farms, both the first and the second cut were always harvested, and the leys were maintained for three production years. Since stockless farms were overrepresented in the south, the leys were more often used for green manure in the south; in the northwest, where livestock farms dominated, both cuts were harvested each season, except on one farm (Appendix, Table 2). On the stockless farms, the leys were not fertilized with any top dressings whereas on livestock farms, two- and three-year-old leys with low clover contents were usually amended with urine. The above variations in production line and ley management are representative of organic farming in the coastal regions of Finland.

\section{Soil and herbage data}

Soil data were derived from samples taken either by the regional extension services or, in some cases, by the farmers. Usually one sample composed of 7-8 sub-samples represents $1-2$ ha of acreage. The samples were taken from the top-soil in a standardised procedure (see Lakanen 1969, Jokinen 1983, Peltovuori 1999) and analysed according to the routines described by Vuorinen and Mäkitie (1955). Soil sampling was carried out within a five-year period prior to our survey. No lime, mineral fertilizers or animal manure had been applied to the respective field during at least a year before the soil samples were taken. Soil characteristics of the fields are given in the Appendix, Table 3. During the time span between soil sampling and herbage sampling none of the fields was submitted to any specific amelioration measure, such as improvement of drainage, basic application of lime, or store fertilization. Regular crop rotation, tillage and fertilization regimes were applied on the fields.

On each farm, herbage samples were taken prior to the first and to the second cut of one-, two-, and three-year-old leys (i.e., first, second, and third production year, respectively), whenever leys of these ages were available. In total 41 one-, 26 two-, and 12 three-year-old red clover-grass leys were sampled (Appendix, Table 2). At each sampling, four $0.25 \mathrm{~m}^{2}$ plots were chosen by dividing the longest diagonal across the field into five equal distances. Headlands were avoided. The sampling area was marked with a metal blade rotating around a metal peg driven into the soil with a hammer. A defoliation height of 2-3 cm above soil surface was chosen in order to obtain a measure of total biomass growth. The herbage was cut with shears and separated by hand into two fractions, clover and grass. Monocotyledonous and dicotyledonous weed species were included to the grass fraction; weed infestation was generally very low. The grass and clover samples obtained from each of the four plots were kept separately and dried with air-flow dryers at $25-30{ }^{\circ} \mathrm{C}$ to a constant weight. Every time a drying bin was emptied the water content of four grass and clover samples each was measured by further treatment in an oven. Based on the average water content of $5 \%$, all herbage weights were corrected to DM weights. The weight of the samples was determined to the nearest $0.01 \mathrm{~g}$.

Averaged over years and ley ages, the interval between sampling (by us) and harvest (by the farmers) was ten and three days in the south, and two and eight days in the northwest (first and second cuts, respectively). The actual herbage harvested by the farmers was projected from our biomass measurements with a grassland growth model (see Riesinger et al. 2008). Driving variables in model application comprised daily means of air temperature, relative air humidity, and wind speed, and daily sums of incoming solar radiation, and precipitation. The weather data were obtained from the official weather station closest to the respective farm (Finnish Meteorological Institute 2003). The water holding capacity of the different soil types included 


\section{AGRICULTURAL AND FOOD SCIENCE}

\section{Riesinger, P. \& Herzon, I. Variability of herbage production}

in this study could not be assessed and the parameterisation of a certain clay soil was used throughout all calibrations (see Eckersten et al. 2004). Clovers have a higher temperature optimum than grasses and therefore their proportion in mixed leys is expected to increase with time (Halling et al. 2004). However, the proportions of clover at the time of leys being cut by farmers could not be estimated and were therefore assumed to be the same both in observed and simulated growth.

\section{Statistical analysis}

The grass and clover fractions from the four plots in each field were pooled for the analyses of herbage production and clover proportion on a field level. Herbage production and clover proportion were related to ley age, soil properties, and geographical location by general linear modelling (GLM) in Statistical Package for the Social Sciences (SPSS 2003). The first and the second cuts were analysed both separately and combined as accumulated herbage production.

To approximate normal distribution and to reduce heteroscedasticity, values of herbage production were log-transformed and clover proportions arcsin-transformed prior to the analyses. Soil properties were summarised by principle component analysis (PCA) prior to the analyses of variance. The full model thus included the explanatory variables ley age and region (both as factors), their interaction, and soil properties summarised as two first PCA gradients. Herbage production was also expressed as a function of clover proportion.

Some soil properties differed by region (Appendix, Table 3 ) and therefore these variables were confounded in the analyses. Running a manual stepwise selection of variables allowed us to detect the confounding effects at intermediate stages of modelling (cf. Sah et al. 2006). The relative weight of each variable on its own and in combination with all others was assessed. Variables with a high degree of explanation were retained in the final model. Non-significant main effect variables (that is, factors) were removed only when their interac- tion was not significant. $p$-values above 0.05 were used as a cut-off point in the removal of explanatory variables.

We considered the possible confounding effect of annual differences in weather conditions. Differences in herbage production and clover proportions between the two sampling years were checked by t-tests with Duncan-Šidak corrections for multiple testing. Within-field variation was expressed as the coefficient of variation of the four sub-samples from each field.

\section{Results}

Estimation of the growth increment between when our data were taken and when the farmers harvested, with a grassland growth model, showed that the farmers' harvest was on average 13.2\% higher than the values we obtained. On the other hand, our samples were cut $2-3 \mathrm{~cm}$ above soil surface, less than half of the defoliation height common in agricultural practice. Herbage production, determined both directly from the samples and indirectly from the grassland growth model was related to ley age, soil properties, and geographical location. Since the results were the same for both, only results of analyses based on our observed data are reported here.

Averaged over both coastal regions and all ley ages and separately for each region and for one- and two-year-old leys, none of the two tested response variables differed significantly between the years 2001 and 2002 (t-test with Duncan-Šidak correction, $p>0.05$ ). For further analyses the data recorded during the two sampling years were pooled. The first two PCA gradients of soil properties explained $57 \%$ of the variance in soil data. The first gradient (soil-PCA1) was positively related to $\mathrm{pH}$-value and concentrations of $\mathrm{P}$ and $\mathrm{K}$, and negatively to humus content. The second gradient (soil-PCA2) was positively correlated with cation exchange capacity (CEC), and with concentrations of $\mathrm{K}$ and $\mathrm{Mg}$. The mean score of soil-PCA2 was significantly higher in the south than in the northwest (Table 1). 
Vol. 17 (2008): 394-412.

Table 1. Principle component analysis (PCA) of soil properties of fields cropped organically with red clover-grass leys in the coastal regions of Finland.

\begin{tabular}{|c|c|c|}
\hline & Soil-PCA1 ${ }^{\mathrm{a}}$ & Soil-PCA2 ${ }^{\mathrm{a}}$ \\
\hline Cation exchange capacity & -0.356 & 0.724 \\
\hline Humus content & -0.736 & -0.141 \\
\hline $\mathrm{pH}$ & 0.832 & -0.025 \\
\hline $\mathrm{P}$ concentration & 0.623 & -0.396 \\
\hline $\mathrm{K}$ concentration & 0.562 & 0.585 \\
\hline Mg concentration & 0.110 & 0.567 \\
\hline$\%$ of variance & $34.6 \%$ & $22.8 \%$ \\
\hline Mean value (SD) for south ${ }^{\mathrm{b}}$ & $1.8(0.58)$ & $0.4(0.85)$ \\
\hline Mean value (SD) for northwest ${ }^{\mathrm{b}}$ & $0.3(1.38)$ & $-0.5(0.99)^{* * *}$ \\
\hline
\end{tabular}

a PCA1 and PCA2 refer to gradients 1 and 2, respectively, of principle component analysis.

${ }^{\mathrm{b}}$ South $=$ southern coastal region, northwest $=$ north-western coastal region.

$* * *=p<0.001$

\section{First and second cut}

Averaged over one-, two- and three-year-old leys, herbage production in the first cut was $20.4 \%$ higher than in the second cut (t-test, $p<0.001$ ). The proportion of clover increased from $26.4 \%$ in the first to $43.7 \%$ in the second cut (t-test, $p<0.001$ ) but decreased in both cuts with ley age. Between- and within-field variations of clover proportions were higher than those of herbage production (Tables 2, 3 and 4).

Herbage production in the first cut positively correlated with soil-PCA1. The first cut was poorly predicted by the model, as indicated by a low percentage of the explained variance (Table 5). Herbage production in the second cut positively correlated with soil-PCA2. Explanatory variables retained in the final model for herbage production in the second cut also included the proportions of clover both in the first (negative correlation) and in the second cut (strong positive correlation) (Table 5). Levels of between- and within-field variations of herbage production differed only slightly between the first and the second cut. Within-field variation of herbage production decreased from one- to three-year-old leys (Tables 2 and 4).
The proportions of clover in both cuts generally declined with ley age (Table 6). In the first cut there was a significant interaction between ley age and region (Table 6): in the south, the proportion of clover in the first cut markedly declined with increasing age while it remained relatively unchanged in the northwest (Fig. 2a). Observed clover proportions were consistently lower in the northwest but in the first cut the difference was significant only for one-year-old leys (Table 6). In the second cut, the proportions of clover declined in both regions markedly with ley age (Fig. 2b). Clover proportion in the second cut was positively correlated with soil-PCA2 (Table 6). Between- and within-field coefficients of variation of clover proportions decreased markedly from the first to the second cut and increased in both cuts with ley age (Tables 3 and 4). The coefficients of within-field variation of clover proportions in the first and in the second cuts of one- and two-year-old leys were significantly higher at lower proportions of clover $\left(\mathrm{R}^{2}>0.6\right.$; $p<$ 0.001 ); in three-year-old leys this relationship was considerable, although not significant $\left(\mathrm{R}^{2}>0.4 ; p\right.$ $>0.1$ ) (Fig. 3). 


\section{AGRICULTURAL AND FOOD SCIENCE}

\section{Riesinger, P. \& Herzon, I. Variability of herbage production}

Table 2 . Herbage production (dry matter $=\mathrm{DM}$ ) in organically cropped perennial red clover-grass leys in the coastal regions of Finland, averaged over two sampling years (means; standard deviations in parenthesis).

\begin{tabular}{|c|c|c|c|c|c|c|}
\hline & \multicolumn{2}{|c|}{ First cut $\left(\mathrm{t} D M \mathrm{ha}^{-1}\right)$} & \multicolumn{2}{|c|}{ Second cut $\left(\mathrm{t} \mathrm{DM} \mathrm{ha}{ }^{-1}\right)$} & \multicolumn{2}{|c|}{ Accumulated production ${ }^{\mathrm{a}}\left(\mathrm{t} \mathrm{DM} \mathrm{ha}^{-1}\right)$} \\
\hline & South $^{\mathrm{b}}$ & Northwest ${ }^{\mathrm{b}}$ & South $^{\mathrm{b}}$ & Northwest ${ }^{\mathrm{b}}$ & South $^{\mathrm{b}}$ & Northwest ${ }^{\mathrm{b}}$ \\
\hline One-year- & 3.92 & 3.98 & 3.86 & 3.47 & 7.78 & 7.45 \\
\hline old leys & $(1.26)$ & $(1.10)$ & $(1.01)$ & $(0.98)$ & $(1.26)$ & $(1.59)$ \\
\hline Two-year- & 3.67 & 4.52 & 3.49 & 3.16 & 7.17 & 7.68 \\
\hline old leys & (1.48) & $(1.00)$ & $(1.34)$ & $(1.08)$ & $(2.18)$ & $(1.65)$ \\
\hline Three-year- & 3.46 & 3.80 & 2.80 & 2.61 & 6.26 & 6.40 \\
\hline old leys & $(1.16)$ & $(0.68)$ & $(1.99)$ & $(0.60)$ & $(1.56)$ & $(1.09)$ \\
\hline All ages & 3.69 & 4.10 & 3.38 & 3.08 & 7.07 & 7.18 \\
\hline & $(1.30)$ & $(0.93)$ & $(1.45)$ & $(0.89)$ & (1.67) & (1.44) \\
\hline
\end{tabular}

${ }^{a}$ Accumulated production $=$ accumulated first and second cuts.

${ }^{\mathrm{b}}$ South $=$ southern coastal region $(\mathrm{n}=47)$, northwest $=$ north-western coastal region $(\mathrm{n}=32)$.

Table 3. Proportions of clover in organically cropped perennial red clover-grass leys in the coastal regions of Finland, averaged over two sampling years (means; standard deviations in parenthesis).

\begin{tabular}{|c|c|c|c|c|c|c|}
\hline & \multicolumn{2}{|c|}{ First cut $(\%)$} & \multicolumn{2}{|c|}{ Second cut (\%) } & \multicolumn{2}{|c|}{ Accumulated production ${ }^{\mathrm{a}}(\%)$} \\
\hline & South $^{\mathrm{b}}$ & Northwest $^{\mathrm{b}}$ & South $^{\mathrm{b}}$ & Northwest $\mathrm{t}^{\mathrm{b}}$ & South $^{b}$ & Northwest ${ }^{b}$ \\
\hline One-year- & 57.3 & 24.1 & 73.4 & 51.2 & 66.2 & 36.8 \\
\hline old leys & $(23.7)$ & $(14.6)$ & $(17.3)$ & $(19.4)$ & $(19.6)$ & $(15.7)$ \\
\hline Two-year- & 33.0 & 20.4 & 56.8 & 38.9 & 44.5 & 28.1 \\
\hline old leys & $(23.9)$ & (17.6) & $(22.4)$ & $(23.8)$ & $(21.0)$ & (18.7) \\
\hline Three-year- & 8.9 & 14.6 & 27.0 & 14.7 & 18.1 & 15.3 \\
\hline old leys & (5.9) & $(25.9)$ & $(22.8)$ & $(10.0)$ & $(13.9)$ & (18.7) \\
\hline All ages & 33.1 & 19.7 & 52.4 & 34.9 & 42.9 & 26.71 \\
\hline & $(17.8)$ & (19.4) & $(20.8)$ & $(17.7)$ & $(18.2)$ & (17.7) \\
\hline
\end{tabular}

${ }^{\mathrm{a}}$ Accumulated production $=$ accumulated first and second cuts.

${ }^{\mathrm{b}}$ South $=$ southern coastal region $(\mathrm{n}=47)$, northwest $=$ north-western coastal region $(\mathrm{n}=32)$.

Table 4. Coefficients of within-field variation of herbage production and clover proportion in organically cropped leys in the coastal regions of Finland, averaged over two sampling years.

\begin{tabular}{|c|c|c|c|c|c|c|c|c|}
\hline & \multicolumn{4}{|c|}{ First cut $(\%)$} & \multicolumn{4}{|c|}{ Second cut (\%) } \\
\hline & \multicolumn{2}{|c|}{ South ${ }^{a}$} & \multicolumn{2}{|c|}{ Northwest ${ }^{\mathrm{a}}$} & \multicolumn{2}{|c|}{ South ${ }^{\mathrm{a}}$} & \multicolumn{2}{|c|}{ Northwest ${ }^{\mathrm{a}}$} \\
\hline & Herbage & Clover & Herbage & Clover & Herbage & Clover & Herbage & Clover \\
\hline One-year-old leys & 20.7 & 32.8 & 20.5 & 82.6 & 19.9 & 18.4 & 22.5 & 41.0 \\
\hline Two-year-old leys & 17.5 & 58.5 & 11.9 & 70.6 & 22.0 & 28.9 & 15.9 & 51.5 \\
\hline Three-year-old leys & 16.1 & 98.3 & 11.6 & 99.0 & 9.9 & 60.8 & 17.1 & 101.0 \\
\hline All ley ages & 18.1 & 63.2 & 14.6 & 84.1 & 17.3 & 36.0 & 18.5 & 64.5 \\
\hline
\end{tabular}

a South $=$ southern coastal region $(n=47)$, northwest $=$ north-western coastal region $(n=32)$. 
Vol. 17 (2008): 394-412.

Table 5. Results of general linear modelling of herbage production in organically cropped leys in the coastal regions of Finland $(n=79)$.

\begin{tabular}{|c|c|c|c|c|}
\hline Term & $\beta$ & $\mathrm{df}$ & $\mathrm{F}$ & $p$ \\
\hline \multicolumn{5}{|c|}{ First cut $\left(R_{a d j .}^{2}=0.067\right)$} \\
\hline Intercept & 8.174 & 1 & 54559.919 & $<0.001$ \\
\hline $\mathrm{PCA}^{\mathrm{a}}$ & 0.084 & 1 & 5.533 & 0.021 \\
\hline Error & & 76 & & \\
\hline \multicolumn{5}{|c|}{ Second cut $\left(R_{a d j .}^{2}=0.33\right)$} \\
\hline Intercept & 7.727 & 1 & 11077.186 & $<0.001$ \\
\hline Clover $1^{\mathrm{b}}$ & -0.315 & 1 & 5.000 & 0.028 \\
\hline Clover $^{\mathrm{b}}$ & 0.780 & 1 & 28.951 & $<0.001$ \\
\hline $\mathrm{PCA}^{\mathrm{a}}$ & 0.098 & 1 & 6.133 & 0.016 \\
\hline Error & & 74 & & \\
\hline \multicolumn{5}{|c|}{ Accumulated production ${ }^{c}\left(R_{a d j .}^{2}=0.22\right)$} \\
\hline Intercept & 8.713 & 1 & 27465.614 & $<0.001$ \\
\hline $\mathrm{PCA}^{\mathrm{a}}$ & 0.051 & 1 & 4.710 & 0.033 \\
\hline $\mathrm{PCA}^{\mathrm{a}}$ & 0.071 & 1 & 7.123 & 0.009 \\
\hline Clover $^{\mathrm{b}}$ & 0.194 & 1 & 5.685 & 0.020 \\
\hline Northwest ${ }^{\mathrm{d}}$ & 0.124 & 1 & 5.284 & 0.024 \\
\hline Error & & 73 & & \\
\hline \multicolumn{5}{|c|}{$\begin{array}{l}\text { a PCA1 and PCA2 refer to principle component analysis gradients } 1 \text { and 2, which represent soil properties (see Ta } \\
1 \text { for details). }\end{array}$} \\
\hline
\end{tabular}

\section{Accumulated herbage production}

The herbage production accumulated from the first and the second cut of one-, two- and three-year-old leys averaged $7.12 \mathrm{tDM} \mathrm{ha}^{-1}\left(\mathrm{SD}=1.55 \mathrm{tDM} \mathrm{ha}^{-1}\right)$, with a clover proportion of $34.8 \%(\mathrm{SD}=17.9 \%)$. Coefficients of between-field variation averaged over one- and two-year-old leys were higher with respect to proportion of clover $(38.3 \%$ in the south; $54.9 \%$ in the northwest) than with respect to accumulated herbage production $(23.3 \%$ and $21.3 \%$, respectively). Similarly, coefficients of within-field variation of clover proportions (34.7\% in the south; $61.4 \%$ in the northwest) exceeded those of herbage production $(20.0 \%$ and $17.7 \%$, respectively) (Tables 2, 3 and 4).
Accumulated herbage production correlated positively with soil-PCA1 and soil-PCA2. Other explanatory variables retained in the final model for accumulated herbage production included region (slightly higher production estimate for the northwest), and proportion of clover in the second cut (positive correlation). An initially significant decline of accumulated herbage production in three-year-old leys became non-significant once soil properties or proportion of clover were fitted into the model (Table 5).

The proportions of clover in accumulated herbage production progressively declined with ley age and correlated positively with soil-PCA2. The large regional difference in proportion of clover decreased in the model estimates after ley age and regional differences in soil properties were taken 


\section{AGRICULTURAL AND FOOD SCIENCE}

\section{Riesinger, P. \& Herzon, I. Variability of herbage production}

Table 6. Results of general linear modelling of clover proportion in organically cropped leys in the coastal regions of Finland $(n=79)$.

\begin{tabular}{|c|c|c|c|c|}
\hline Term & $\beta$ & df & $\mathrm{F}$ & $p$ \\
\hline \multicolumn{5}{|c|}{$\overline{\text { First cut }\left(R^{2}{ }_{\text {adj. }}=0.286\right)}$} \\
\hline Intercept & 0.089 & 1 & 54.188 & $<0.001$ \\
\hline Ley age $\mathrm{I}^{\mathrm{a}}$ & 0.571 & 2 & 5.002 & 0.001 \\
\hline Ley age II $^{\mathrm{a}}$ & 0.268 & & & ns \\
\hline Region & 0.91 & 1 & 2.167 & ns \\
\hline Ley age $\mathrm{x}$ region & & 2 & 3.298 & 0.035 \\
\hline \multicolumn{5}{|l|}{ Ley age $\mathrm{I}^{\mathrm{a}} \mathrm{x}$ region } \\
\hline Northwest ${ }^{\mathrm{b}}$ & -0.499 & & & 0.017 \\
\hline Ley age $\mathrm{II}^{\mathrm{a}} \mathrm{x}$ region & & & & ns \\
\hline Ley age $I I I^{\mathrm{a}} \mathrm{x}$ region & & & & ns \\
\hline Error & & 72 & & \\
\hline \multicolumn{5}{|c|}{ Second cut $\left(R_{a d j .}^{2}=0.506\right)$} \\
\hline Intercept & 0.348 & 1 & 236.411 & $<0.001$ \\
\hline Ley age $\mathrm{I}^{\mathrm{a}}$ & 0.465 & 2 & 14.850 & $<0.001$ \\
\hline Ley age II $^{\mathrm{a}}$ & 0.271 & & & 0.002 \\
\hline $\mathrm{PCA} 2^{\mathrm{c}}$ & 0.089 & 1 & 9.147 & 0.003 \\
\hline Northwest ${ }^{\mathrm{b}}$ & -0.177 & 1 & 3.796 & ns \\
\hline Error & & 73 & & \\
\hline \multicolumn{5}{|c|}{ Accumulated production ${ }^{d}\left(R_{a d j .}^{2}=0.46\right)$} \\
\hline Intercept & 0.191 & 1 & 147.467 & $<0.001$ \\
\hline Ley age $\mathrm{I}^{\mathrm{a}}$ & 0.537 & 2 & 11.112 & $<0.001$ \\
\hline Ley age $\mathrm{II}^{\mathrm{a}}$ & 0.268 & & & 0.047 \\
\hline $\mathrm{PCA} 2^{\mathrm{c}}$ & 0.064 & 1 & 4.544 & 0.036 \\
\hline Northwest ${ }^{\mathrm{b}}$ & 0.019 & 1 & 4.134 & 0.046 \\
\hline Ley age $\mathrm{x}$ region & & 2 & 2.442 & ns \\
\hline \multicolumn{5}{|l|}{ Ley age $\mathrm{I}^{\mathrm{a}} \mathrm{x}$} \\
\hline Northwest & -0.329 & & & 0.049 \\
\hline Ley age $\mathrm{II}^{\mathrm{a}} \mathrm{x}$ region & & & & ns \\
\hline Ley age $\mathrm{III}^{\mathrm{a}} \mathrm{x}$ region & & & & ns \\
\hline Error & & 71 & & \\
\hline
\end{tabular}

${ }^{a}$ Ley age I, II and III = one-, two- and three-year-old leys, respectively.

${ }^{\mathrm{b}}$ North-western region as compared to the southern region.

c PCA1 and PCA2 refer to principle component analysis gradients 1 and 2, which represent soil properties (see Table 1 for details).

${ }^{\mathrm{d}}$ Accumulated production $=$ accumulated first and second cuts.

into account. Similarly to the first cut, there was an interaction between region and ley age: only in one-year-old leys, the proportion of clover was significantly higher in the south than in the northwest (Table 6).

\section{Discussion}

General patterns of clover growth observed here, such as proportional increase from the first to the second cut and proportional decrease with increasing 
Vol. 17 (2008): 394-412.

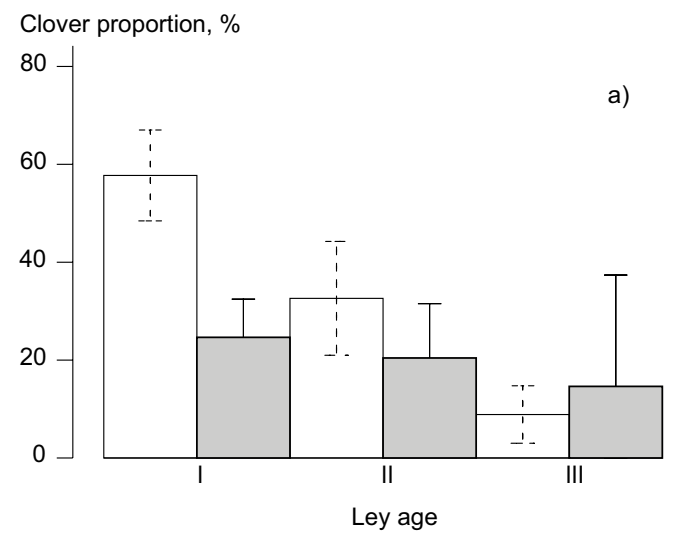

Fig. 2a. Clover proportions (mean and SE) in the first cuts obtained from one-, two- and three-year-old (I, II and III, respectively) organically cropped leys in the southern and the north-western coastal regions of Finland (south $=$ open bar, northwest $=$ closed bar).

ley age, corroborate previous reports from northern Europe (Frame et al. 1985, Fagerberg and Ekbohm 1995, Mela 2003). As confirmed by other studies of legume-grass leys not amended with easily-soluble $\mathrm{N}$ fertilizers, herbage production was dependent on the proportion of clover (Mallarino and Wedin 1990, Newton 1995, Mela 2003). Since clover growth was more variable than that of grass, increased withinfield variation of herbage production in the second cut was attributable to the more dominating role of clover in the regrowth taking place subsequent to the first cut. The decline of herbage production with ley age observed in this study was associated with a decline of clover proportion (see also Mela 2003). Accordingly, an increase of herbage production from one- to two-year-old leys and a less marked decline of herbage production from two- to three-year old leys, as reported from Finland by Nykänen et al. (2000), and from Finland and Sweden by Halling et al. (2001), were associated with higher proportions of clover. Thus, both establishment and persistence of clover are decisive for the herbage production of mixed leys.

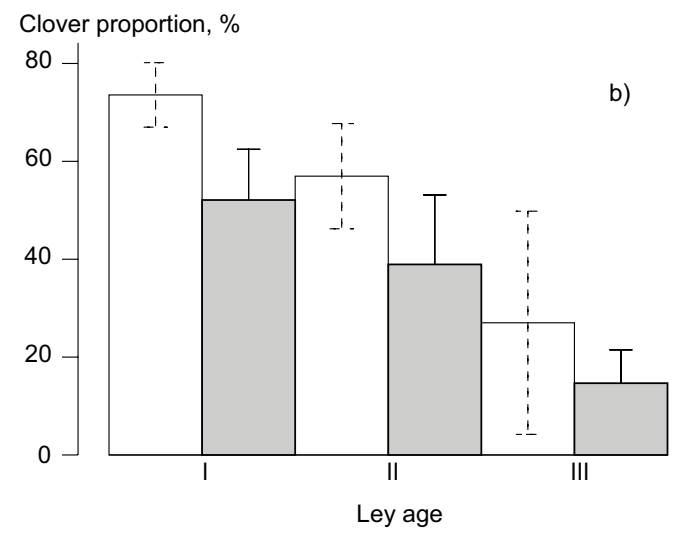

Fig. 2b. Clover proportions (mean and SE) in the second cuts obtained from one-, two- and three-year-old (I, II and III, respectively) organically cropped leys in the southern and the north-western coastal regions of Finland (south $=$ open bar, northwest $=$ closed bar).

Within-field variation of clover proportion, CV

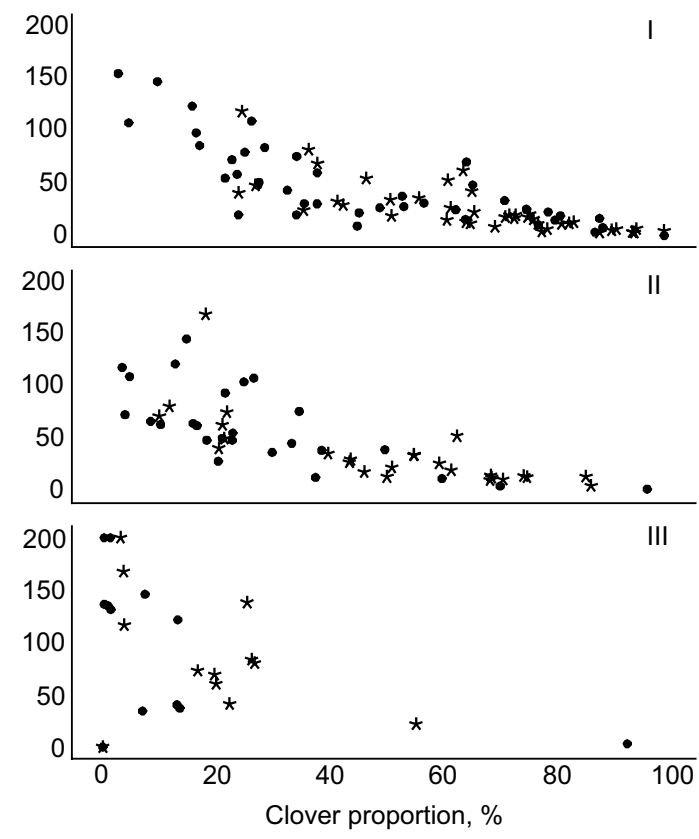

Fig. 3. The relationship between clover proportions in the first and in the second cuts (dots and stars, respectively) of one-, two-, and three-year-old leys (I, II, and III, respectively) and the coefficients of within-field variations of clover proportions in these cuts. 


\section{AGRICULTURAL AND FOOD SCIENCE}

\section{Riesinger, P. \& Herzon, I. Variability of herbage production}

\section{Variability of herbage production and clover proportion}

The herbage production obtained by the farmers corresponded to the levels recorded in field experiments carried out in Finland and Sweden but did not reach the levels achieved in northern Germany and Great Britain (Halling et al. 2001). Clover proportions were somewhat lower compared to the northern European field experiments reported by Halling et al. (2001). Annual variation in ley growth cannot be explored with data limited to two years and could therefore not be related to the observations of Mela (2003) and Herrmann et al. (2005) on large year-to-year fluctuations of herbage production. Three-year-old leys could be sampled only in a minor number of fields so the data presented here on three-year-old leys, as well as trends in yields and proportions of clover from two- to three-year-old leys have to be interpreted with caution.

Between- and within-field variations of clover proportions were considerably larger than those of herbage production, emphasising that the viability of red clover more than that of grasses was affected by climate, soil, and management factors (see also Fagerberg and Ekbohm 1995, Nykänen et al. 2000). Between-field variation of clover proportion declined from the first to the second cut (cf. Nykänen et al. 2000) but increased with ley age.

The proportions of clover in the seed mixtures used for the establishment of the leys studied here potentially entail a domination of clover in the herbage production of one-year-old leys. In a considerable number of cases, however, the proportions of clover in the herbage production of one-year-old leys were below $40 \%$. With proportions of clover lower than $40 \%$, the coefficients of within-field variation of clover proportions markedly increased to between 50 and $150 \%$. A decrease of within-field variation of clover proportion from the first to the second cut indicated that the vigour of clover improved during the growing period. With increasing ley age, however, patterns of decreasing clover proportion and increasing withinfield variation of clover proportion became more pronounced. Establishment during the first grow- ing season and persistence during the first winter were factors markedly influencing the proportion of clover and its variability not only during the first production year but throughout the whole production cycle of a ley crop.

Red clover is a stationary plant that grows from a crown, an area of meristematic tissue, sitting just above the soil surface. Loss or damage to this crown prevents new plant growth and is the major cause of mortality in red clover. White clover, by contrast, spreads and perennates by stolons. These horizontal stems have many growing points and can assume independent existence. Its stoloniferous growth habit enables white clover to colonise bare spaces and to establish itself in available niches (Abberton and Marshall 2005). The herbage production of white clover-grass swards oscillates at patch scale, but might, through spatial heterogeneity, be stabilised at field scale (Schulte et al. 2003). Thus, white clover might contribute to a stabilisation of clover proportions in mixed leys. However, white clover is more sensitive to drought than red clover (Frame et al. 1998). Furthermore, low canopies impair the competitiveness of many white clover varieties relative to other ley species (Frame et al. 1998, Høgh-Jensen et al. 2001). The development of large-leaved white clover varieties with drought tolerance and good winter survival remains a challenge for plant breeding in boreal climate conditions.

\section{Impact of soil properties on ley growth}

Within our study fields, soil probes had been taken from places not identical with the plots sampled for herbage. According to the soil test protocols, the surveyed fields were uniform with respect to soil type, humus content, $\mathrm{pH}$, and $\mathrm{P}-, \mathrm{K}-, \mathrm{Mg}$-, and $\mathrm{Ca}-$ concentrations. However, spatial and temporal heterogeneity of soil properties within single fields is known to be high (Geypens et al. 1999, Shi et al. 2002). Moreover, analysis of soil nutrient status according to the routines applied in Finland usually only entails the easily-soluble nutrient fraction (see Vuorinen and Mäkitie 1955), and this was also 
Vol. 17 (2008): 394-412.

the case in our study. Another reason for cautious interpretation of our results is that ley growth is also influenced by other plant nutrients than those studied here. Plant growth may also be obstructed by soil compaction (Alakukku 1999). Our study provides indications of relationships between ley growth and soil properties along summarised PCA gradients rather than their exact values. Thus, we discuss only strong correlations between soil-PCA gradients and ley growth.

Both herbage production and clover proportion were clearly related to soil properties. Although confounded by regional location, soil properties had stronger correlations with growth parameters than region. Similarly, Mela (2003) concluded that soil type was more important for the persistence of red clover than latitude. Levels of herbage production and of clover proportions were positively related to a soil gradient determined by CEC, i.e., to increasing nutrient and water exchange capacity. Soil nutrient stocks are, especially in conditions of organic farming, decisive for crop growth (Fortune et al. 2005). Being a function of clay and humus contents, high CEC is often synonymous with high nutrient mobilisation capacity (Thomsen et al. 2003) and favourable soil structure (Strong et al. 1998).

Good soil structure increases the water-holding capacity of the soil and the proportion of plantavailable soil water, and enhances root growth, and thus the total amounts of plant-available soil water and nutrients. This is of importance for crop growth in the coastal regions of Finland, where especially the second ley growth in certain years is limited by summer drought (Mukula and Rantanen 1987); in the case of our study, incidences of summer drought differed between regions and years. Soil structure also influences the overwintering ability of biennial and perennial crops: there are fewer incidents of waterlogging and flooding on permeable soils (Lindén et al. 1999).

Symbiotic $\mathrm{N}_{2}$ fixation provides ley legumes with a competitive advantage relative to grasses. However, the efficiency of symbiotic $\mathrm{N}_{2}$ fixation depends, among other factors, on gas exchange between soil and atmosphere, and access to soil water (see Giller and Cadisch 1995). The observation by Mela (2003) that red clover persisted better on humus-rich and thus well-aerated sandy soils than on heavy clay and silt soils might, in this context, be related to beneficial soil structure rather than to a specific soil texture.

Although humus level is indicative of the amounts of nutrients contained in soil organic matter and available for plant growth through mineralisation, a soil gradient related to humus content correlated negatively with herbage production. This could have been caused by a number of negative consequences that a high level of soil organic matter may have for the viability of red clover. Humus-rich and organic soils in northern latitudes originally have low $\mathrm{pH}$, which is known to be unfavourable for the persistence of red clover (Bowley et al. 1984). Furthermore, in Nordic climate conditions, high content of soil organic matter implies a risk for frost-heaving, to which red clover and meadow fescue are more sensitive than timothy (Pulli 1986, Nissinen and Hakkola 1995). On humus-rich and organic soils extensive mineralisation of soil-N decreases the competitiveness of the legume relative to the grass component. More vigorous grass growth may in this case compensate the lower viability of legumes; in our study, however, this was not the case.

The negative correlation between humus content and proportion of clover was very weak. Thus, instead of being caused by factors detrimental solely to red clover the negative correlation between humus content and herbage production was obviously related to factors adverse both to clovers and grasses. Extensive uptake of $\mathrm{N}$ during late summer and autumn has negative effects on hardening and viability of overwintering crops (Bélanger et al. 2006). Frost heaving may have affected both clovers and grasses. Finally, humus-rich soils are often located in low-lying grounds, which are prone to flooding. Poor overwintering of both clovers and grasses is a probable cause for the negative correlation between humus content and herbage production.

The positive relation of herbage production with a gradient of soils characterised by high $\mathrm{pH}$ values and high concentrations of $\mathrm{P}$ and $\mathrm{K}$ corroborated other studies (Wheeler 1998, Pant et al. 2004, 


\section{AGRICULTURAL AND FOOD SCIENCE}

\section{Riesinger, P. \& Herzon, I. Variability of herbage production}

Schils and Snijders 2004). Clover proportion was not related to the gradient summarising soils with high $\mathrm{pH}$ values. This was surprising since red clover requires a higher $\mathrm{pH}$ than grasses (Pires et al. 1992). Most of the surveyed fields had neutral $\mathrm{pH}$ values and rather high humus contents. Neutral $\mathrm{pH}$ values promote the mineralisation of $\mathrm{N}$ from soil organic matter and thus an increase of the proportion of grasses at the expense of legumes (Ledgard and Steele 1992). The gradient of soil parameters, to which levels of clover proportions were related, included low soil-P and high soil- $\mathrm{K}$ and $-\mathrm{Mg}$ concentrations, although nutrient concentrations were less clearly related to the gradient than CEC. Most of the studies on the influence of different plant nutrients on the performance of clovers relative to that of grasses have been done in white clover-ryegrass communities. More factorial laboratory and field experiments are needed to investigate the influence of plant nutrients other than $\mathrm{N}$ on the competitiveness of red clover in mixed leys.

\section{Impact of climate on ley growth}

The main effects of climate on ley growth were attributable to overwintering conditions. The detrimental impact of unfavourable overwintering conditions on the first cut was in both regions expressed by higher between- and within-field variations of clover proportions as compared to the second cut. This might also explain the particularly weak relationship of herbage production and clover proportion in the first cut to soil properties and to weather conditions during the growing period (that is, to the region).

Patterns of ley growth differed between the two regions: In the south, accumulated herbage production decreased with ley age, while in the northwest it increased from one- to two-year-old leys. Especially in one-year-old leys, the proportion of clover was remarkably lower in the northwest. Furthermore, between- and within-field variations of clover proportion were considerably higher in the northwest than in the south. The lower proportion of clover and the higher variability of clover con- tents recorded in the northwest might be related to climate conditions such as shorter growing season and lower temperature sum (cf. Halling et al. 2004). However, weather data obtained from the official meteorological stations closest to the respective farms and included to the statistical modelling as explanatory variables did not yield any significant results. Climate conditions were therefore represented by the factor region.

The effect of region on ley growth was partly confounded by soil properties. The moist mull and capillary silt soils frequent in the northwest are more sensitive to frost heaving than the clay soils dominating along the southern coastline. Ice encasement and flooding are promoted by even topography, independently of soil type and humus contents; the proportion of such fields is considerably larger in the northwest than in the south (Mukula and Rantanen 1987). Although regional location involved somewhat different climatic conditions, ley age and soil properties proved to be more decisive explanatory variables for herbage production and clover proportion.

\section{Impact of management on ley growth}

The red clover-grass leys studied here were grown for harvest, green manure, or both. In the northwest, ley cultivation aimed at production of forage whereas in the south, the leys were grown for forage or green manure, or both. Mulching the herbage may have both positive and negative effects on subsequent ley growth. $\mathrm{N}$ mineralised from mulched herbage may have a positive effect especially on grass growth. However, considerable amounts of $\mathrm{N}$ mineralised from mulched herbage can be volatilised (Whitehead and Lockyer 1989) or leached (Bergström and Kirchmann 2004). Also other nutrients, such as $P$ and $\mathrm{K}$, can be lost from the field either by leaching or in surface runoff (Ulén and Mattsson 2003, Kayser et al. 2007). The amounts of plant nutrients mineralised from mulched herbage are relatively small compared to those mobilised from previous applications of animal manure (Uusitalo et al. 2007) and from the soil stock (Kaila 1967, Saarela 2002). 
Therefore, the residual effect of mulched herbage on subsequent ley growth may be minimal (cf. Nykänen 2008). Since mulched herbage covers the stubble, the regrowth of the sward may even be hampered by shading. Here we assumed that ley growth subsequent to mulching was not markedly different from that subsequent to herbage harvest.

Within each field, weather conditions and management measures were consistent, and withinfield variation was therefore related to spatial differences in soil properties and in field topography, and possibly to minor variations in fertilization and sowing. Although differences in ley growth between single fields and farms are driven not only by climate conditions and soil properties but also by management measures, the levels of variability in herbage production and clover proportion between fields and farms were similar to those within fields. This leads to the question whether soil properties were mainly responsible also for the variability of herbage production and clover proportion between fields and farms.

The farms were managed according to the regulations of organic farming (European Council 1991), and neither easily-soluble mineral fertilizers nor pesticides were applied to the fields. Thus, the differentiating impact of management on the organically cropped leys studied by us was smaller compared with conventionally managed leys, where fertilizers and pesticides have considerable impacts on crop growth (Pulli 1980, Hyvönen and Salonen 2003). Whereas management has strong influences on the growth of conventionally cropped leys, soil properties may be more decisive than management for the growth of organically cropped mixed leys. In a longer perspective, however, management not only directly affects crop growth but also determines it indirectly through changes in soil fertility.

\section{Conclusions}

Yield levels and growth patterns of the red clovergrass leys studied in this farm survey corresponded to findings reported from northern European field trials. Growth of mixed leys in the southern and the north-western coastal regions of Finland appeared to be mainly related to ley age and soil properties, and only to a minor degree to geographical location. Knowledge established under conditions of factorial laboratory and field experiments was necessary for the interpretation of the observed relationships. We could show that herbage production was mainly driven by clover proportion. However, the persistence of clovers was poor and the importance of grasses for the stability of herbage production increased with ley age. Mixed leys that are maintained for three production years should, under conditions of organic cultivation, be fertilized in the second production year, preferably after the first cut; grass-dominated swards have a high demand especially of N. Variability of herbage production and clover proportion within fields was surprisingly high and equalled levels of variability between fields and farms. High variability of clover proportions between and within fields complicates feeding management as well as calculations of the preceding crop value of leys. Amelioration of fields and, not at least, of less fertile sites within the same field seems to be a crucial requirement for higher and more even clover proportions and herbage yields.

Acknowledgements. The authors thank the farmers whose fields were surveyed, Dr Henrik Eckersten and Dr Bengt Torssell for introduction to growth modelling, Dr Frederick Stoddard for linguistic revision and detailed comments on the manuscript, and two referees for valuable suggestions. Financial support received by P. Riesinger from the R. Erik Serlachius foundation and the Göran and Louise Ehrnrooth foundation is gratefully acknowledged. 


\section{AGRICULTURAL AND FOOD SCIENCE}

\section{Riesinger, P. \& Herzon, I. Variability of herbage production}

\section{Appendix}

Appendix, Table 1. Weather conditions during the growing seasons 2001 and 2002 (Finnish Meteorological Institute 2003).

\begin{tabular}{lcc}
\hline & South $^{\mathrm{a}}$ & Northwest $^{\mathrm{a}}$ \\
\hline Growing season (days) & \\
2001 & $176-177$ & $175-176$ \\
2002 & $161-163$ & $147-148$ \\
30 -year mean & $178-190$ & $164-172$ \\
Temperature sum $\left({ }^{\circ} \mathrm{C}\right)^{\mathrm{c}}$ & & \\
2001 & $1439-1626$ & $1169-1361$ \\
2002 & $1536-1693$ & $1405-1499$ \\
30 -year mean & $1313-1386$ & $1104-1180$ \\
Precipitation $(\mathrm{mm})^{\mathrm{d}}$ & & \\
2001 & $91-185$ & $137-231$ \\
2002 & $111-229$ & $182-273$ \\
30 -year mean & $135-161$ & $128-148$ \\
\hline
\end{tabular}

${ }^{a}$ South $=$ southern coastal region, northwest $=$ north-western coastal region. Range between different weather stations located within the respective coastal region (five stations in the south, three stations in the northwest).

${ }^{\mathrm{b}}$ Calculated in days when the base temperature of $5{ }^{\circ} \mathrm{C}$ is exceeded.

${ }^{\mathrm{c}}$ Calculated by accumulation of the mean daily temperatures above $5{ }^{\circ} \mathrm{C}$ during the growing period.

${ }^{\mathrm{d}}$ Including May, June and July (the period during which the first and the second ley growth take place).

Appendix, Table 2. Number of crops included in the study of organically cropped red clover-grass leys by ley age and ley management (in parenthesis: two harvests, one harvest and one green manure cut, and two green manure cuts, respectively).

\begin{tabular}{lcc}
\hline & South $^{\mathrm{a}}$ & Northwest $^{\mathrm{a}}$ \\
\hline One-year-old leys $^{\mathrm{b}}$ & $27(9,9,9)$ & $14(13,1,0)$ \\
Two-year-old leys $^{\mathrm{b}}$ & $16(9,6,1)$ & $10(10,0,0)$ \\
Three-year-old leys $^{\mathrm{b}}$ & $4(3,1,0)$ & $8(8,0,0)$ \\
\hline
\end{tabular}

${ }^{\text {a }}$ South $=$ southern coastal region, northwest $=$ north-western coastal region.

${ }^{\mathrm{b}}$ One-, two-, and three-year-old leys refer to ley age (production years subsequent to the establishment year). In 12 cases samples were taken from the same site during two consecutive years. 
Vol. 17 (2008): 394-412.

Appendix, Table 3. Number of sites included in the study of organically cropped red clover-grass leys by soil properties.

\begin{tabular}{|c|c|c|}
\hline & South ${ }^{\mathrm{a}}$ & Northwest ${ }^{\mathrm{a}}$ \\
\hline \multicolumn{3}{|l|}{$\overline{\text { Soil type }}{ }^{b}$} \\
\hline Sand & 2 & 11 \\
\hline Silt & 6 & 8 \\
\hline Clay & 39 & 7 \\
\hline Mull & 0 & 6 \\
\hline \multicolumn{3}{|l|}{ Humus content $(\%)^{c}$} \\
\hline$<1.5$ & 0 & 0 \\
\hline $1.5-2.9$ & 0 & 0 \\
\hline $3.0-5.9$ & 33 & 14 \\
\hline $6.0-11.9$ & 7 & 9 \\
\hline $12.0-19.9$ & 7 & 3 \\
\hline $20.0-39.9$ & 0 & 6 \\
\hline \multicolumn{3}{|l|}{ pH-value $\left(\mathrm{H}_{2} \mathrm{O}\right)$} \\
\hline $5.0-5.4$ & 1 & 5 \\
\hline $5.5-5.9$ & 17 & 15 \\
\hline $6.0-6.4$ & 22 & 6 \\
\hline $6.5-6.9$ & 7 & 6 \\
\hline \multicolumn{3}{|l|}{ Soil-P concentration ${ }^{\mathrm{d}}$} \\
\hline Poor & 0 & 1 \\
\hline Quite poor & 2 & 0 \\
\hline Satisfactory & 12 & 14 \\
\hline Good & 24 & 5 \\
\hline High & 8 & 4 \\
\hline Very high & 1 & 6 \\
\hline Hazardously high & 0 & 2 \\
\hline \multicolumn{3}{|l|}{ Soil-K concentration $^{\mathrm{d}}$} \\
\hline Poor & 0 & 0 \\
\hline Quite poor & 2 & 16 \\
\hline Satisfactory & 13 & 8 \\
\hline Good & 21 & 5 \\
\hline High & 11 & 3 \\
\hline Very high & 0 & 0 \\
\hline Hazardously high & 0 & 0 \\
\hline \multicolumn{3}{|c|}{ Soil-Mg concentration $^{\mathrm{d}}$} \\
\hline Poor & 5 & 2 \\
\hline Quite poor & 5 & 0 \\
\hline Satisfactory & 6 & 6 \\
\hline Good & 15 & 16 \\
\hline High & 11 & 8 \\
\hline Very high & 5 & 0 \\
\hline Hazardously high & 0 & 0 \\
\hline
\end{tabular}

${ }^{\text {a }}$ South $=$ southern coastal region, northwest $=$ north-western coastal region.

${ }^{\mathrm{b}}$ Soil types are categorised according to Mukula and Rantanen (1987), with the exception of silt, which is defined as the particle range $0.002-0.06 \mathrm{~mm}$. Moraine soils are included with sandy soils. Cation exchange capacity (CEC) increases from sand, silt, and clay to mull soils. For the purpose of principle component analysis (PCA), increasing CEC was expressed by the numerical values 1, 2, 3, and 4, respectively (see Table 1).

${ }^{\mathrm{c}}$ Humus contents are categorised according to Mukula and Rantanen (1987). For the purpose of PCA, the humus classes 3.0-5.9, 6.0-11.9, 12.0-19.9, and 20.0-39.9 were expressed by the numerical values $1,2,3$, and 4, respectively (see Table 1).

${ }^{\mathrm{d}}$ Concentrations of plant-available soil-P, $-\mathrm{K}$ and $-\mathrm{Mg}$ are grouped in seven classes (Vuorinen and Mäkitie 1955). For the purpose of PCA, corresponding numerical values were used. 


\title{
AGRICULTURAL AND FOOD SCIENCE
}

\author{
Riesinger, P. \& Herzon, I. Variability of herbage production
}

\section{References}

Abberton, M.T. \& Marshall, A.H. 2005. Progress in breeding perennial clovers for temperate agriculture. Journal of Agricultural Science 143: 117-135.

Acuña, P.G.H. \& Wilman, D. 1993. Some effects of added phosphorus on perennial ryegrass-white clover swards. Grass and Forage Science 48: 416-420.

Alakukku, L. 1999. Subsoil compaction due to wheel traffic. Agricultural and Food Science in Finland 8: 333-351.

Bélanger, G., Castonguay, Y., Bertrand, A., Dhont, C., Rochette, P., Couture, L., Drapeau, R., Mongrain, D., Chalifour, F.-P. \& Michaud, R. 2006. Winter damage to perennial forage crops in eastern Canada: Causes, mitigation, and prediction. Canadian Journal of Plant Science 86: 33-47.

Belzile, L. 1987. Effet de la présence de la fléole des prés sur la survie à I' hiver du trèfle rouge. Canadian Journal of Plant Science 67: 1101-1103.

Bergkvist, G. 2003. Effect of white clover and nitrogen availability on the grain yield of winter wheat in a three-season intercropping system. Acta Agriculturae Scandinavica, Section B, Soil and Plant Science 53: 97-109.

Bergström, L. \& Kirchmann, H. 2004. Leaching and crop uptake of nitrogenfrom nitrogen-15-labeled green manures and ammonium nitrate. Journal of Environmental Quality 33: 1786-1792.

Bowley, S.R., Taylor, N.L. \& Dougherty C.T. 1984. Physiology and morphology of red clover. Advances in Agronomy 37: 317-347.

Brennan, R.F. \& Bolland, M.D.A. 2006. Comparing the potassium requirements of five pasture species. Australian Journal of Experimental Agriculture 46: 659-667.

Eckersten, H., Torssell, B., Kornher, A. \& Olsson, U. 2004. Modelling radiation use and regrowth in grass and red clover swards - method of calibration. Ecology of Crop Production Science 5. Swedish University of Agricultural Sciences, Uppsala. $50 \mathrm{p}$.

European Council 1991. European Council Regulation (EC) No. 2092/91. Available on the Internet: http://europa. eu.int/eur-lex/en/consleg/main/1991/en_1991R2092_ index.html. Last accessed 3 November 2004.

Fagerberg, B. \& Ekbohm, G. 1995. Variation in clover content and in nutritional value of grass-clover leys. Uppsala: Swedish University of Agricultural Sciences. Crop Production Science 23. 46 p.

Finnish Meteorological Institute 2003. Meteorological data. Helsinki.

Fortune, S., Robinson, J.S., Watson, C.A., Philipps, L., Conway, J.S. \& Stockdale, E.A. 2005. Response of organically managed grassland to available phosphorus and potassium in the soil and supplementary fertilization: field trials using grass-clover leys cut for silage. Soil Use and Management 21: 370-376.

Frame, J., Charlton, J.F.L. \& Laidlaw, A.S. 1998. Temperate forage legumes. Wallingford: CAB International. $327 \mathrm{p}$.

Frame, J., Harkess, R.D. \& Hunt, I.V. 1985. Effect of seed rate of red clover and of companion timothy or tall fescue on herbage production. Grass and Forage Science 40: 459-465.

Geypens, M., Vanongeval, L., Vogels, N. \& Meykens, J.
1999. Spatial variability of agricultural soil fertility parameters in a gleyic podzol of Belgium. Precision Agriculture 1: 319-326.

Giller, K.E. \& Cadisch, G. 1995. Future benefits from biological nitrogen fixation: an ecological approach to agriculture. Plant and Soil 174: 255-277.

Griffin, T., Giberson, E. \& Wiedenhoeft, M. 2002. Yield response of long-term mixed grassland swards and nutrient cycling under different nutrient sources and management regimes. Grass and Forage Science 57: 268-278.

Halling, M.A., Hopkins, A., Nissinen, O., Paul, C., Tuori, M. \& Soelter, U. 2001. Forage legumes - productivity and composition. Landbauforschung Völkenrode 234: 5-15.

Halling, M.A., Topp, C.F.E. \& Doyle, C.J. 2004. Aspects of the productivity of forage legumes in Northern Europe. Grass and Forage Science 59: 331-344.

Herrmann, A., Kelm, M., Kornher, A. \& Taube, F. 2005. Performance of grassland under different cutting regimes as affected by sward composition, nitrogen input, soil conditions and weather - a simulation study. European Journal of Agronomy 22: 141-158.

Høgh-Jensen, H., Fabricius, V. \& Schjoerring, J.K. 2001. Regrowth and nutrient composition of different plant organs in grass-clover canopies as affected by phosphorus and potassium availability. Annals of Botany 88: 153-162.

Høgh-Jensen, H. \& Pedersen, M.B. 2003. Morphological plasticity by crop plants and their potassium use efficiency. Journal of Plant Nutrition 26: 969-984.

Høgh-Jensen, H. \& Schjoerring, J.K. 1997. Interactions between white clover and ryegrass under contrasting nitrogen availability: $\mathrm{N}_{2}$ fixation, $\mathrm{N}$ fertilizer recovery, $\mathrm{N}$ transfer and water use efficiency. Plant and Soil 197: 187-199.

Hopkins, A. \& Wilkins, R.J. 2006. Temperate grassland: key developments in the last century and future perspectives. Journal of Agricultural Science 144: 503-523.

Hyvönen, T. \& Salonen, J. 2003. Weed seedbank development under low-input and conventional cropping practices. Aspects of Applied Biology 69: 119-124.

Jørgensen, M., Schjelderup, I. \& Junttila, O. 1994. Dry matter production and botanical composition of monocultures and mixtures of meadow fescue (Festuca pratensis Huds.) and timothy (Phleum pratense L.) in field experiments at three locations in northern Norway 1984-89. Norwegian Journal of Agricultural Sciences 8: 291-299.

Jokinen, R. 1983. Variability of topsoil properties at the southern coast of Finland and the number of soil samples needed for the estimation of soil properties. Journal of the Scientific Agricultural Society of Finland 55: 109-117.

Kaila, A. 1967. Release of nonexchangeable potassium from Finnish mineral soils. Journal of the Scientific Agricultural Society of Finland 39: 45-56.

Känkänen, H., Eriksson, C., Räkköläinen, M. \& Vuorinen, M. 2001. Effect of annually repeated undersowing on cereal grain yields. Agricultural and Food Science in Finland 10: 197-208.

Kayser, M., Mueller, J. \& Isselstein, J. 2007. Potassium leaching from cut grassland and from urine patches. 
Vol. 17 (2008): 394-412.

Soil Use and Management 23: 384-392.

Kirkham, F.W., Mountford, J.O. \& Wilkins, R.J. 1996. The effects of nitrogen, potassium and phosphorus addition on the vegetation of a Somerset peat moor under cutting management. Journal of Applied Ecology 33: 1013-1029.

Lager, J. 2002. Soil-borne clover diseases in intensive legume cropping. PhD thesis. Uppsala: Department of Plant Pathology and Biocontrol Unit. Swedish University of Agricultural Sciences. Agraria 362. 29 p.

Lakanen, E. 1969. Viljavuustutkimuksen analyysitarkkuudesta. Summary: On the accuracy of soil testing analysis in Finland. Agrogeological Publications 76: 1-33.

Ledgard, S.F. \& Steele, K.W. 1992. Biological nitrogen fixation in mixed legume/grass pasture. Plant and Soil 141: 137-153.

Lindén, L., Palonen, P., Seppänen, M. \& Väinölä, A. 1999 Cold hardiness research on agricultural and horticultural crops in Finland. Agricultural and Food Science in Finland 8: 459-477.

Mallarino, A.P. \& Wedin, W.F. 1990. Effect of species and proportion of legume on herbage yield and nitrogen concentration of legume-grass mixtures. Grass and Forage Science 45: 393-402.

Mela, T. 2003. Red clover grown in a mixture with grasses: yield, persistence and dynamics of quality characteristics. Agricultural and Food Science in Finland 12: 195-212.

Mengel, K. \& Steffens, D. 1985. Potassium uptake of ryegrass (Lolium perenne) and red clover (Trifolium pratense) as related to root parameters. Biology and Fertility of Soils 1: 53-58.

Mukula, J. \& Rantanen, O. 1987. Climatic risks to the yield and quality of field crops in Finland. I. Basic facts about Finnish field crop production. Annales Agriculturae Fenniae 26: 1-18.

Newton, J.E. 1995. Herbage production from organic farms. Journal of the Royal Agricultural Society of England 156: 24-34.

Nissinen, O. \& Hakkola, H. 1995. Effects of plant species and harvesting system on grassland production in northern Finland. Food and Agriculture in Finland 4: 479-494.

Nykänen, A. 2008. Nitrogen dynamics of organic farming in a crop rotation based on red clover (Trifolium pratense) leys. PhD thesis. Jokioinen: MTT Agrifood Research Finland. Agrifood Research Reports $121.60 \mathrm{p}$.

Nykänen, A., Granstedt, A., Laine, A. \& Kunttu, S. 2000. Yields and clover contents of leys of different age in organic farming in Finland. Biological Agriculture and Horticulture 18: 55-66.

Ozanne, P.G. \& Petch, A. 1978. Effect of species and cultivation on the responses to phosphate of annual pastures and crops. Australian Journal of Agricultural Research 29: 225-233.

Pant, H.K., Mislevy, P. \& Rechcigl, J.E. 2004. Effects of phosphorus and potassium on forage nutritive value and quantity: environmental implications. Agronomy Journal 96: 1299-1305.

Peltovuori, T. 1999. Precision of commercial soil testing practice for phosphorus fertilizer recommendations in Finland. Agricultural and Food Science in Finland 8: 299-308.
Pires, A.L., Ahlrichs, J.L. \& Rhykerd, C.L. 1992. Response of eleven forage species to treatment of acid soil with calcitic and dolomitic lime. Communications of Soil Science and Plant Analysis 23: 541-558.

Pulli, S. 1980. Growth factors and management technique used in relation to the developmental rhythm and yield formation pattern of a pure grass stand. Journal of the Scientific Agricultural Society of Finland 52: 281-330.

Pulli, S. 1986. Climatic factors in relation to winter hardiness. Lantbruksväxternas övervintring. NJF Seminar No. 84, Jokioinen. p. 48-58.

Raininko, K. 1968. The effects of nitrogen fertilisation, irrigation and number of harvestings upon leys established with various seed mixtures. PhD thesis. Helsinki: Department of Plant Husbandry. University of Helsinki. Acta Agralia Fennica 112. 133 p.

Riesinger, P., Eckersten, H., Torssell, B. \& Forkman J. 2008. Radiation-use efficiency in leys: influences of growth period and clover proportion. Acta Agriculturae Scandinavica, Section B, Soil and Plant Science. In print.

Ritchey, K.D., Belesky, D.P. \& Halvorson, J.J. 2004. Soil properties and clover establishment six years after surface application of calcium-rich by-products. Agronomy Journal 96: 1531-1539.

Rufelt, S. 1986. Studies on Fusarium root rot of red clover (Trifolium pratense L.) and the potential for its control. PhD thesis. Uppsala: Department of Plant and Forest Protection. Swedish University of Agricultural Sciences. Plant protection reports $10.33 \mathrm{p}$.

Saarela, I. 2002. Phosphorus in Finnish soils in the 1900's with particular reference to the acid ammonium acetate soil test. Agricultural and Food Science in Finland 11: 257-271.

Sah, S.P., Rita, H. \& Ilvesniemi, H. 2006. ${ }^{15} \mathrm{~N}$ natural abundance of foliage and soil across boreal forests of Finland. Biogeochemistry 80: 307-318.

Schiere, J.B., Lyklema, J., Schakel, J. \& Rickert, K.G. 1999. Evolution of farming systems and system philosophy. Systems Research and Behavioral Science 16: 375-390.

Schils, R. \& Snijders, P. 2004. The combined effect of fertiliser nitrogen and phosphorus on herbage yield and changes in soil nutrients of a grass/clover and grassonly sward. Nutrient Cycling in Agroecosystems 68: 165-179.

Schjønning, P., Elmholt, S. \& Christensen, B.T. 2004. Soil quality management - synthesis. In: Schjønning, P., Elmholt, S. \& Christensen, B.T. (eds) Managing soil quality: challenges in modern agriculture. Wallingford: CABI Publishing. p. 315-333.

Schulte, R.P.O., Lantinga, E.A. \& Struik, P.C. 2003. Analysis of the production stability of mixed grasslands I: A conceptual framework for the qualification of production stability in grassland ecosystems. Ecological Modelling 159: 43-69.

Shi, Z., Wang, K., Bailey, J.S., Jordan, C. \& Higgins, A.H. 2002. Temporal changes in the spatial distributions of some soil properties on a temperate grassland site. Soil Use and Management 18: 353-362.

Simpson, D., Wilman, D. \& Adams, W.A. 1988. Response of white clover and grass to applications of potassium and nitrogen on a potassium-deficient hill soil. Journal of Agricultural Science, Cambridge 110: 159-167. 


\section{AGRICULTURAL AND FOOD SCIENCE}

\section{Riesinger, P. \& Herzon, I. Variability of herbage production}

SPSS 2003. Statistical Package for the Social Sciences. SPSS Inc. Chicago, Illinois. See http://www.spss. com/corpinfo/history.htm. Last accessed 10 November 2008.

Stenberg, B. 1998. Soil attributes as predictors of crop production under standardized conditions. Biology and Fertility of Soils 27: 104-112.

Strong, D.T., Sale, P.W.G. \& Helyar, K.R. 1998. The influence of the soil matrix on nitrogen mineralisation and nitrification. I. Spatial variation and a hierarchy of soil properties. Australian Journal of Soil Research 36: 429-447.

Thomsen, I.K., Schjønning, P., Olesen, J.E. \& Christensen, B.T. 2003. $\mathrm{C}$ and $\mathrm{N}$ turnover in structurally intact soils of different texture. Soil Biology and Biochemistry 35: 765-774.

Ulén, B. \& Mattsson, L. 2003. Transport of phosphorus forms and of nitrate through a clay soil under grass and cereal production. Nutrient Cycling in Agroecosystems 65: 129-140.
Uusitalo, R., Ylivainio, K. \& Turtola, E. 2007. Accumulation and translocation of sparingly soluble manure phosphorus in different types of soils after long-term excessive inputs. Agricultural and Food Science 16: 317-331.

Vuorinen, J. \& Mäkitie, O. 1955. The method of soil testing in use in Finland. Agrogeological Publications 63: 1-44.

Wheeler, D.M. 1996. Solution concentrations required for near maximum yield in ryegrass and white clover when grown in a low ionic strength solution: preliminary results. Journal of Plant Nutrition 19: 565-572.

Wheeler, D.M. 1998. Investigation into the mechanisms causing lime response in a grass/clover pasture on a clay loam soil. New Zealand Journal of Agricultural Research 41: 497-515.

Whitehead, D.C. \& Lockyer D.R. 1989. Decomposing grass herbage as a source of ammonia in the atmosphere. Atmospheric Environment 23: 1867-1869.

Wivstad, M. 1997. Green manure crops as a source of nitrogen in cropping systems. PhD thesis. Uppsala: Swedish University of Agricultural Sciences. Agraria 34. 29 p. 